\title{
Local vs. Global Brands: Country-of-Origin's Effect on Consumer-based Brand Equity among Status-Seekers
}

\author{
Sheng Yang CHIU, Jessica Sze Yin HO* \\ Sunway University Business School, Malaysia \\ jessicah@sunway.edu.my*
}

\begin{abstract}
This paper examines the local and global automotive brands in conjunction with country-oforigin effect on consumer-based brand equity. Consumer's level of status-seeking motivation is considered when analysing the effect of brand's country-of-origin on consumer-based brand equity. Study conducted on 181 respondents showed that consumers generally prefer Asian than European automotive brands. Asian brands also ranked highest in perceived quality and brand loyalty, followed by European brands and local brands. The main difference of high and low status-seeking consumers is found in brand association, perceived quality, and brand loyalty of local brands. Low status-seeking consumers tend to rate brand association, perceived quality, and brand loyalty of local brands higher than high statusseeking consumers. This paper exhibits that the theory of consumer ethnocentrism and global branding strategies are not mutually exclusive.
\end{abstract}

Keywords: Country-of-Origin, Consumer-Based Brand Equity, Status-Seeking Motivation, Global and Local Brands, Automobile Industry

\section{Introduction}

The rapid globalization and increased international business activity have caused the emergence of global market, where products are available outside its home country (Hsieh, 2002).For years; consumers have been relying on the impression of country-of-origin (COO) as a guidance for making purchasing decisions, especially when they are flooded with enormous amount of choices from both local and global brands. Akerlof (1970) explained the concept of "lemons" in the context of the automobile industry, as consumers may misrepresent the true quality of automobiles because they are too complicated for consumers to evaluate and consumers may lack knowledge on automobile. It is therefore important to manage brand equity because of its strategic role of gaining competitive advantage and influencing consumer decision making. However, to manage brand equity, managers must develop a thorough understanding of its formative factors (Jalilvand, Samiei \& Mahdavinia, 2011). The connection between COO and brand equity have encouraged a few researchers in the past to address the dimensions of brand equity and relationship of COO and brand equity (Roth, Diamantopoulos \& Montesinos, 2008; Hamzaoui-Essoussi, Merunka \& Bartikowski, 2011). In the recent years Roy and Chau (2011) and Ho, Ong, Wang, Tay, and New (2012), have researched on global versus local brands on the automobile industry. Although consumers may summarize the information to an accessible level, summarizing information to global and local level may be too vague. Therefore, this research investigates at a regional level, a more accessible level as compared to $\mathrm{COO}$ but not as vague as global and local level.

The automobile industry is a fully-branded industry as no manufacturer would invest heavily in production, marketing, and advertising of automobile without branding it. Malaysia is the country with highest car-ownership-to-people ratio in ASEAN, with 200 car ownership in every one thousand people (Malaysian Investment Development Authority, 2012). The automobile industry is experiencing a growth of an average of two to four percent for 2012-2014, where market share for local automobile companies $(58.1 \%)$ is not far ahead of the market share for foreign automobile companies (41.9\%) (Malaysia Automotive Association, 2014). Automobile companies achieve performance through aggressive marketing campaign. The automobile companies have spent RM260 million by the first six months of 2013 (Marketing Magazine, 2013). The Malaysian automotive context of the competitive yet highlysubsidized local automotive sector and demand for global automotive brands provides a right context fit for this study. Hence, this research examines the relationship between COO (Local, Asia and Europe) and consumer-based brand equity of automobile industry in Malaysia. This study further examines the difference in the relationship of $\mathrm{COO}$ and consumer-based brand equity between high and low statusseekers. 


\section{Literature Review}

Country-of-Origin: Country-of-origin (COO) is used as a cognitive cue for consumers to evaluate a product (Ditcher, 1962). It is an intangible product attribute and extrinsic cue for consumers to evaluate a product when product information is insufficient or difficult to manage (Huber \& McCann, 1982). COO creates a halo effect and a summary of product information which helps consumers to make inferences and abstraction of the product based on the country's image they had in their mind (Sharma, 2011). Products from a certain COO may have a symbolic and emotional meaning in relation to their national identity, feeling, and status (Shukla, 2011).Brands from countries with favourable images are better received by consumers than brands from countries with unfavourable images (Verlegh, Steenkamp\& Meulenberg, 2005; Yasin, Noor \& Mohamad, 2007). COO consists of brand origin (BO) and country-ofmanufacture ( $\mathrm{COM})$. $\mathrm{BO}$ is the country associated by consumers to the product, regardless of the place where the product was produced; whereas COM is the country where the branded product was produced or assembled (Moradi \& Zarei, 2012). The issue of BO and COM was being researched since the 1980s. However, COM has slowly become irrelevant and the importance has slowly shifted towards BO as manufacturers shift to the best possible location to be cost-effective (Parkvithee \& Miranda, 2012). Thus, many companies position their brands with respect to their national origin (Balabanis \& Diamantopoulos, 2008; Shukla, 2011).

Consumers prefer global brands as global brands are often associated with status, wealth and prestige of consumers, which enhance their social standings (Alden, Steenkamp \& Batra, 1999). On the other hand, consumers may also prefer local brands as they display consumer ethnocentrism for various reasons, such as fear of loss of jobs due to import of global brands and the unpatriotic sense when purchasing global brands (Kaynak \& Kara, 2002). Besides that, local brands can better position as 'sons of the soil' to directly identify with consumers' own local traditions, customs, and culture (Cayla \& Eckhardt, 2008). This research will test $\mathrm{COO}$ and global and local brand in conjunction with the automobile industry of Malaysia to find out its relationship with consumer-based brand equity (CBBE) for local brands, Asian brands, and Europe brands.

Consumer-Based Brand Equity: CBBE is defined as "a set of brand assets and liabilities linked to a brand, its name and symbol that adds to or subtracts from the value provided by a product or service to a firm and/or to that firm's customers" (Aaker, 1991, p.15). CBBE is the added value of a brand in the mind of consumers, allowing companies to charge a premium price (Keller, 1998). This research will use Aaker's model of CBBE. All CBBE models consist of one or more components in Aaker's model (Keller, 1993; Bendixen, Bukasa \& Abratt, 2004). Besides that, it is the most widely cited and accepted framework. The Aaker's model consists of brand awareness, brand association, perceived quality, and brand loyalty (Aaker, 1991). A global brand is preferred because: 1) it is perceived to be of higher quality (Pappu, Quester \& Cooksey, 2007); 2) it communicates added value by way of membership to global consumer community (McCraken, 1986); and 3) it is associated with higher prestige (Kapfere, 1997). However, the preference towards global brand may be moderated by factors like consumer ethnocentrism wherein local consumers may take pride in the countries' brand symbols and culture (Steenkamp, Batra \& Alden, 2003).

Brand Awareness: Brand Awareness is a key dimension of the customer-based brand equity model and it is included in most models (Aaker, 1991; Keller, 1993; Agarwal \& Rao, 1996). Aaker (1991) and Keller (1993) explained that brand recall and recognition are the most important component and measurement of brand awareness. Researchers also conceptualized the measurement for brand awareness on recall and recognition (Yoo \& Donthu, 2001). Brand awareness is the first step to the development of brand equity and it could affect brand association, brand choice, and brand loyalty (Shahin, Kazemi \& Mahyari, 2012). Research on high-involvement products found brand awareness to be the most significant customer-based brand equity (Im, Kim, Elliot \& Han, 2012). In many studies, brand awareness acts as a component by itself and it is an important component rather than a joint component with brand association (Yoo \& Donthu, 2001; Pappu, Quester \& Cooksey., 2005).Countries with good images are often familiar to consumers and are perceived to be producers of quality brands (Yasin et al., 2007). This helps in consumers' recall and recognition process because brand can differentiate itself with brand origin (Keller, 2002). Research has found brand origin and brand awareness to be significantly related in the audio-visual appliance industry (Shahin et al., 2012). Thus, this research hypothesized that:

H1: Brand Awareness varies significantly for local, Asian, and European brands. 
Brand Association: Brand association is "anything that linked in memory to a brand" (Aaker, 1991, p. 109). It consists of image-making, product's profile, consumer's conditions, awareness, brand characteristics, sign, symbol, and so forth (Aaker and Joachimsthaler, 2000). It helps in providing value to the company, retrieving information, creating positive feeling, and providing a reason to buy the product (Aaker, 1991). A set of brand association also forms brand identity (Yasin et al., 2007). Brand association usually consists of dimensions that are unique to a product category or to a brand (Aaker, 1996). Keller (1993) noted that the uniqueness, desire, and power of brand association are necessary. Brand origin, being a secondary association and extrinsic cue, is considered as one of the source to brand image. This secondary association would affect brand association because consumer with knowledge of brand origin would associate the brand with positive or negative association (Shahin et al., 2012). There are empirical evidences that prove the said relationship (Yasin et al., 2007; Moradi \& Zarei, 2012; Shahin et al., 2012). However, they were all tested in electronic appliance industry. Pappu et al. (2005) has tested the relationship in the context of passenger car. However, the research was testing COM instead of BO. The researcher also landed support from Amonini, Keogh and Sweeney (1998), stating that the importance of COM or BO to CBBE may be product or situation specific. Thus, this research hypothesized that:

$\mathrm{H} 2$ : Brand Association varies significantly for local, Asian, and European brands.

Perceived Quality: Aaker (1996) stated that perceived quality is the core component to customer-based brand equity. Perceived quality is explained as the way customer thinks the brand will perform its intent purpose as compared to alternative rather than its actually quality (Zeithaml, 1988). Perceived quality incorporates all the benefits and attributes that form a perception in the mind of consumers, from basic functional characteristics, performance and the life of the product (Takali, Hamidi, Khabiri, Sajjadi \& Alhani, 2012). Research showed that perceived quality is essential for CBBE as it adds more value for customer's purchase (Low \& Lamb, 2000). Brand origin image is consumers' general perception about the quality of a product from a particular country (Han \& Terpstra, 1988). Brand origin of a product influences consumers' perception of a product's quality (Pappu et al., 2005, 2007). However, the study of Hamzaoui-Essoussi et al. (2011), using passenger cars from Korea and Germany in Tunisia has found contradicting result. As perceived quality placed of brand equity may vary across cultures (Jung \& Shen, 2011), this research tests in the context of Malaysia. Thus, this research hypothesized that:

H3: Perceived Quality varies significantly for local, Asian, and European brands.

Brand Loyalty: Aaker (1991) defined brand loyalty as the attachment of a customer to a brand. Javalgi and Moberg (1997) defined brand loyalty in two perspectives: behavioural loyalty and attitudinal loyalty. Behavioural loyalty is the actual repeat purchase of a brand or the commitment to re-buy a brand over time (Keller, 2002). Attitudinal loyalty is the tendency to choose a certain brand as the first choice (Oliver, 1997). This study adopts the definition of brand loyalty as "the tendency to be loyal to a focal brand, which is demonstrated by the intention to buy the brand as a primary choice" (Yoo \& Donthu, 2001, p. 3). Most of the time, brand loyalty is as a subset of brand equity because consumers tend to be loyal to the brand with strong brand equity to them (Moradi \& Zarei, 2012).Countries with favourable images have high level of brand popularity and in turn, led to consumer brand loyalty (Kim, 1995). Country's image acts as a "halo" effect when consumers have limited knowledge of the product (Erickson, Johansson\& Chao, 1984). Research also showed that BO and brand loyalty are significantly related (Shahin et al., 2012). Conflicting empirical evidence was also found to prove the relationship insignificant (Moradi \& Zarei, 2012). However, both researches were done in laptops, mobile phones, and audio visual electronic appliances. This research will then test in the passenger car industry. Thus, this research hypothesized that:

H4: Brand Loyalty varies significantly for local, Asian, and Europe brands.

Status-Seeking Motivation: Eastman, Goldsmith and Flynn (1999) defined status consumption as "the motivational process by which individual strives to improve his social standing through the conspicuous consumption of consumer products that confer and symbolize status both for the individual and surrounding significant others." Status consumption is the process of gaining status or social prestige through acquiring products that are associated with high social status (Jung \& Shen, 2011). Consumption of status or symbolic product helps in enhancing social recognition and self-concept (Eastman et al. 1999). According to Scitovsky (1976), goods can be classified into necessities and luxuries categories. While necessities do not fluctuate according to income, luxuries do as disposable income increases. Most global brands are often treated as luxury brand and are associated with prestige. Thus, different status-seekingmotivation consumers may have different preferences over global brands (Roy \& Chau, 2011). Status- 
seeking consumers are more likely to purchase luxury brands than non-status-seeking consumers in order to satisfy their symbolic needs (Eastman et al., 1999).

H5: Brand awareness varies significantly with status consumption motive for (a) local brand, (b) Asian brand, and (c) European brand.

H6: Brand association varies significantly with status consumption motive for (a) local brand, (b) Asian brand, and (c) European brand.

H7: Perceived quality varies significantly with status consumption motive for (a) local brand, (b) Asian brand, and (c) European brand.

H8: Brand loyalty varies significantly with status consumption motive for (a) local brand, (b) Asian brand, and (c) European brand.

\section{Methodology}

The 18-item questionnaire adapted for this study uses a 5-point Likert scale. Five status-seeking motivation items were adapted from Eastman et al. (1999), two brand awareness items were adapted from Yoo and Donthu (2001), two brand association items were adapted from Pappu et al. (2005), five perceived quality items were adapted from Pappu et al. (2005), and four brand loyalty items were adapted from Yoo and Donthu (2001), Pappu et al. (2005), Yasin et al. (2007), and Tong and Hawley (2009). Respondents are required to answer all $13 \mathrm{CBBE}$ item for five different brands. The unit of analysis for this study is for respondents aged 18 or above with a monthly income of RM3, 000 or above in Malaysia. Self-administrated questionnaires are distributed online via social media platform, Facebook, with convenience sampling. Through this method, a total of 181 usable questionnaires were obtained out of 200 questionnaires collected. Data collected are further tested with Cronbach's alpha coefficient to ensure reliability. As Cronbach's alpha ranges between 0.707-0.836 falls between the acceptable range of more than 0.7 (Nunnally, 1978), all items are kept. The data are also tested for normality, where "Eyeball" method of meeting the normality assumption is used (Totton \& White, 2011). First, the presence of bell curve on histogram was examined. Second, the scores on a normal Q-Q plot were examined. Lastly, absence of outliers on the box plot was examined (Totton \& White, 2011). Based on these screenings, the distribution of the data collected complied with normality assumption.

The respondent group comprised of $45 \%$ of male and $55 \%$ of female. Eighty-five percent of the respondents are Chinese, $6 \%$ are Malay, $6 \%$ are Indian and the remaining 3\% of the total respondents consists of other races. Majority of respondents have a Bachelor's Degree (58.6\%), following with PreUniversity/Diploma (24.9\%) and Masters (11\%). Only a small amount of them are with SPM (2.8\%), PhD $(2.2 \%)$ and others $(0.6 \%)$ for their highest level of education. Executive job holders consist of $56.9 \%$, Management and Professional job holders have $12.7 \%$, and $17.7 \%$ of respondents respectively. A median split at 3.6 was also used to split up respondents to high and low status-seeking motivation group. Seventy-five respondents are in high status-seeking motivation group attributed to $41 \%$ of the total respondents, while 106 respondents are in low status-seeking motivation group attributed to $59 \%$ of the total respondents.

\section{Analysis \& Findings}

Paired sample t-test was used to compare means of dimension of CBBE for local, Asian, and European brands. In terms of brand awareness, there is no difference between local brands and European brands $(\mathrm{M}=4.2099$ and $\mathrm{M}=4.2376, \mathrm{p}=0.361>0.05$ ) (shown in Table 1). However, Asian brands $(\mathrm{M}=4.3287$ ) are significantly higher than local brands and European brands $(\mathrm{p}=0.002<0.05$ and $\mathrm{p}=0.001<0.05)$. Therefore, H1 is partially supported.

Brand association, on the other hand, differs significantly between local, Asian, and European brands (shown in Table 1). European brands $(\mathrm{M}=3.6920)$ ranked the highest, followed by Asian brands $(M=3.5041)$ and local brands $(M=1.9392)$. European brands are significantly higher than Asian brands $(\mathrm{p}=0.000<0.05)$ and Asian brands are also significantly higher than local brands $(\mathrm{p}=0.000<0.05)$. Thus, H2 is supported. 
Table 1: CBBE

\begin{tabular}{lllllllll}
\hline \multirow{2}{*}{ CBBE } & COO & Mean & $\begin{array}{l}\text { Local } \\
\text { Mean } \\
\text { Differences }\end{array}$ & $\begin{array}{l}\text { Standard } \\
\text { Deviation }\end{array}$ & Sig & $\begin{array}{l}\text { Asian } \\
\text { Mean } \\
\text { Differences }\end{array}$ & $\begin{array}{l}\text { Standard } \\
\text { Deviation }\end{array}$ & Sig \\
\hline \multirow{2}{*}{ Brand } & Local & 4.2099 & - & - & - & - & - & - \\
Awareness & Asian & 4.3287 & -0.11878 & 0.51745 & 0.002 & - & - & - \\
& Europe & 4.2376 & -0.02762 & 0.40560 & 0.361 & 0.09116 & 0.37078 & 0.001 \\
Brand & Local & 1.9392 & - & - & - & - & - & - \\
Association & Asian & 3.5041 & -1.56492 & 0.94516 & 0.000 & - & - & - \\
\multirow{2}{*}{ Perceived } & Europe & 3.6920 & -1.75276 & 1.10805 & 0.000 & -0.18785 & 0.48298 & 0.000 \\
Quality & Local & 2.0785 & - & - & - & - & - & - \\
& Asian & 3.7619 & -1.68343 & 0.87315 & 0.000 & - & - & - \\
Brand & Europe & 3.6558 & -1.57735 & 0.97187 & 0.000 & 0.10608 & 0.56077 & 0.012 \\
Loyalty & Local & 1.8923 & - & - & - & - & - & - \\
& Asian & 3.3902 & -1.49793 & 0.93546 & 0.000 & - & - & - \\
\hline
\end{tabular}

Asian brands ranked the highest in perceived quality $(M=3.7619)$, followed by Europe brands $(M=3.6558)$, and lastly by local brands $(M=2.0785)$ (shown in Table 1). Asian brands are significantly higher than European brands $(\mathrm{p}=0.012<0.05)$ and European brands are significantly higher than local brands $(\mathrm{p}=0.000<0.05)$. Hence, H3 is supported. Similar results were obtained for brand loyalty (shown in Table 1), where Asian brands ( $M=3.3902)$ ranked the highest, followed by European brands $(M=3.2459)$ and local brands $(\mathrm{M}=1.8923)$. Asian brands are significantly higher than European brands $(\mathrm{p}=0.020<0.05)$ and European brands are significantly higher than local brands $(\mathrm{p}=0.000<0.05)$. Therefore, H4 is supported. MANOVA was used to test the difference between low and high status-seeking motivation groups of respondents (Table 2). There are no significant differences ( $p=0.400>0.05, p=0.176>0.05, p=0.474>0.05$ ) between high and low status-seeking motivation group in brand awareness as they are aware of brands from different region and local brands. Thus, H5 (a), (b), and (c) are not supported. On the other hand, there is a significant difference for local brand's brand association. Low status-seeking respondent group $(M=2.0377)$ rated local brands higher for brand association as compared to high status-seeking respondent group $(\mathrm{M}=1.8000, \mathrm{p}=0.036<0.05)$. Thus, $\mathrm{H} 6(\mathrm{a})$ is supported while $\mathrm{H} 6$ (b) and (c) are not supported.

Table 2: MANOVA Results

\begin{tabular}{lllll}
\hline CBBE & Coo & $\begin{array}{l}\text { Mean } \\
\text { Low }\end{array}$ & $\begin{array}{l}\text { Mean } \\
\text { High }\end{array}$ & Sig \\
\hline \multirow{3}{*}{ Brand Awareness } & Local & 4.2500 & 4.1533 & 0.400 \\
& Asia & 4.2901 & 4.1633 & 0.176 \\
Brand Association & Europe & 4.3042 & 4.3633 & 0.474 \\
& Local & 2.0377 & 1.8000 & 0.036 \\
Perceived Quality & Asia & 3.6934 & 3.6900 & 0.975 \\
& Europe & 3.5448 & 3.4467 & 0.282 \\
& Local & 2.2528 & 1.8320 & 0.000 \\
Brand Loyalty & Asia & 3.5726 & 3.7733 & 0.024 \\
& Europe & 3.7538 & 3.7733 & 0.768 \\
& Local & 2.1156 & 1.5767 & 0.000 \\
& Asia & 3.2229 & 3.2783 & 0.653 \\
\hline
\end{tabular}

There are significant differences between high and low status-seeking respondent for local brands and Asian brands for perceived quality $(p=0.000<0.05, p=0.024<0.05)$. However, there are no significant differences on high and low status-seeking respondent group rates for European brands $(\mathrm{p}=0.768)$. High status-seeking group rated local brands lower than low status-seeking group $(M=1.8320, M=2.2528)$. On the other hand, high status-seeking group rated Asian brands higher than low status-seeking group 
$(M=3.7733, M=3.5726)$. Hence, $H 7$ (a) and (b) are supported but H7 (c) is not supported. In terms of brand loyalty, only local brands showed significant differences between high and low status-seeking motivation groups $(\mathrm{p}=0.000<0.05, \mathrm{p}=0.653>0.05, \mathrm{p}=0.821>0.05)$. High status-seeking respondents rated local brands lower than low status-seeking respondents $(M=1.5767, M=2.1156)$. Thus, H8 (a) is supported while H8 (b) and (c) are not supported.

\section{Discussion, Conclusion \& Recommendations}

This study aims to examine the relationship of global brands from different regions and local brands affecting CBBE of automobile brands in Malaysia. Overall, the results show that global brands have higher CBBE ratings as compared to local brands in terms of brand awareness, brand association, perceived quality, and brand loyalty. The results are similar to the finding of Roy and Chau (2011) and Ho et al. (2012). This strongly supports the various advantages of pursuing a global brand strategy (Steenkamp et al., 2003; Roy \& Chau, 2011). However, findings show that Asian brands ranked the highest overall and in each dimension. The findings are similar to the findings of Ho et al. (2012), where consumers prefer global brands from the same region as the consumers' country. This may be due to the desire of consumers to higher prestige and status of global brands but at the same time their desire also to a brand they could closely relate to. This could suggest that consumer ethnocentrism and brand globalness could go hand-in-hand and may not be mutually exclusive. This was not found in Roy and Chau (2011) research because only one global brand, Toyota, was chosen for the research. Also, high and low status-seeking consumers will not rate global brands differently, except for perceived quality variable. This result is similar to Roy and Chau (2011), except that Roy and Chau (2011) also found that high status-seekers are more aware of global brands than low status-seekers. High status-seeking consumers rate Asian brands higher than low status-seeking consumers. This may be because low status-seeking consumers could not justify the price of Asian automobile brands, as perceived quality may take into consideration of price level (Jung \& Shen, 2011). However, high status-seeking consumers generally rate local brands lower than low status-seeking consumers in all dimension of CBBE except for brand awareness. In Roy and Chau's (2011) research, only brand loyalty is favoured by low status-seekers. There is no significant difference in the knowledge of brands for high and low status-seeking consumers. The lower rating of high statusseeking consumers to local brands may be due to local brands not meeting the consumers' requirements of status and prestige to enhance their social standings.

Unlike previous studies, authors did not take into consideration regional culture characteristics, where consumers may still exercise certain level of consumer ethnocentrism. Based on the theory of consumer ethnocentrism and global branding strategy, it was found that both theories are not mutually exclusive in Malaysia's automobile industry. This is important for the automobile industry as companies wish to pursue a global branding strategy or brand extension strategy in different regions of the world, especially in Asian countries. This study is confined under several limitations which suggest the avenues for future research. Non-probability convenience sampling was used due to budget and time constraint. Future research should use a probability sampling method to avoid bias by the nature of the sampling technique. In addition, it will be a better representation of the whole population. Also, this study did not take into consideration product category as suggested by Pappu, Quester, and Cooksey (2006), as it was suggested that product category may affect the rating on CBBE of certain countries' brands.

\section{References}

Aaker, D. (1991). Managing Brand Equity: Capitalizing on the Value of a Brand Name. New York: Free Press.

Aaker, D. (1996). Measuring Brand Equity across Products and Markets. California Management Review, 38(3), 102-120.

Aaker, D. \& Joachimsthaler, E. (2000). The brand relationship spectrum. California Management Review, 42(4), 8-23.

Agarwal, M. K. \& Rao, V. R. (1996). An empirical comparison of consumer-based brand equity. Marketing Letters, 7(3), 237-247.

Akerlof, G. A. (1970). The market for" lemons": Quality uncertainty and the market mechanism. The quarterly journal of economics, 3, 488-500.

Alden, D. L., Steenkamp, J. B. E. \& Batra, R. (1999). Brand positioning through advertising in Asia, North America and Europe: the role of global consumer culture. The Journal of Marketing, 2, 75-87. 
Amonini, C., Keogh, J. \& Sweeney, J. C. (1998). The Dual Nature of Country-Of-Origin Effects-A Study of Australian Consumers' Evaluations. Australasian Marketing Journal (AMJ), 6(2), 13-27.

Balabanis, G. \& Diamantopoulos, A. (2008). Brand origin identification by consumers: a classification perspective. Journal of International Marketing, 16(1), 39-71.

Bendixen, M., Bukasa, K. A. \& Abratt, R. (2004). Brand equity in the business-to-business market. Industrial Marketing Management, 33(5), 371-380.

Cayla, J. \& Eckhardt, G. M. (2008). Asian brands and the shaping of a transnational imagined community. Journal of Consumer Research, 35(2), 216-230.

Ditcher, E. (1962). The world customer. The International Executive, 4(4), 25-27.

Eastman, J. K., Goldsmith, R. E. \& Flynn, L. R. (1999). Status consumption in consumer behavior: Scale development and validation. Journal of Marketing Theory and Practice, 1, 41-52.

Erickson, G. M., Johansson, J. K. \& Chao, P. (1984). Image variables in multi-attribute product evaluations: country-of-origin effects. Journal of Consumer Research, 4, 694-699.

Hamzaoui-Essoussi, L., Merunka, D. \& Bartikowski, B. (2011). Brand origin and country of manufacture influence on brand equity and the moderating role of brand typicality. Journal of Business Research, 64(9), 973-978.

Han, C. M. \& Terpstra, V. (1988). Country-of-origin effects for uni-national and bi-national products. Journal of international business studies, 3, 235-255.

Ho, J. S. Y., Ong, D. L. T., Wang, P. I., Tay, G. T. P. \& New, C. P. (2012). Global versus local brand: perceived quality and status-seeking motivation in the automobile industry. World Review Business Research, 2(4), 1-12.

Hsieh, M. H. (2002). Identifying brand image dimensionality and measuring the degree of brand globalization: a cross-national study. Journal of International Marketing, 10(2), 46-67.

Huber, J. \& McCann, J. (1982). The impact of inferential beliefs on product evaluations. Journal of Marketing Research, 3, 324-333.

Im, H. H., Kim, S. S., Elliot, S. \& Han, H. (2012). Conceptualizing destination brand equity dimensions from a consumer-based brand equity perspective. Journal of Travel \& Tourism Marketing, 29(4), 385403.

Jalilvand, M. R., Samiei, N. \& Mahdavinia, S. H. (2011). The Effect of Brand Equity Components on Purchase Intention. International Business and Management, 2(2), 149-158.

Javalgi, R. R. G. \& Moberg, C. R. (1997). Service loyalty: implications for service providers. Journal of Services Marketing, 11(3), 165-179.

Jung, J. \& Shen, D. (2011). Brand equity of luxury fashion brands among Chinese and US young female consumers. Journal of East-West Business, 17(1), 48-69.

Kapferer, J. N. (1997). Strategic brand management: creating and sustaining brand equity long term (2nd Ed.). London: Kogan Page Limited.

Kaynak, E. \& Kara, A. (2002). Consumer perceptions of foreign products: An analysis of product-country images and ethnocentrism. European Journal of Marketing, 36(7/8), 928-949.

Keller, K. L. (1993). Conceptualizing, measuring, and managing customer-based brand equity. The Journal of Marketing, 1, 1-22.

Keller, K. L. (1998). Strategic Brand Management: Building, Measuring and Managing Brand Equity. Upper Saddle River, New Jersey: Prentice Hall.

Keller, K. L. (2002). Strategic Brand Management: Building, Measuring and Managing Consumer-Based Brand Equity (2nd Ed). Upper Saddle River, New Jersey: Pearson Education.

Kim, C. K. (1995). Brand popularity and country image in global competition: managerial implications. The Journal of Product and Brand Management, 4(5), 21-33.

Low, G. S. \& Lamb Jr, C. W. (2000). The measurement and dimensionality of brand associations. Journal of Product \& Brand Management, 9(6), 350-370.

Malaysia Automotive Association. (2014). Summary of Sales \& Production Data. Retrieved April 23, 2014, from http://www.maa.org.my/info_summary.htm

Malaysia Investment Development Authority. (2012). Business Opportunities Malaysia's Automotive Malaysia. Retrieved from

http://www.mida.gov.my/env3/uploads/Publications_pdf/BO_MalaysiaAutomotive/Automoti ve2012.pdf

Marketing Magazine. (2013). Never A Better Time for Automotive Marketers. Retrieved April 26, 2014, from http://marketingmagazine.com.my/index.php/categories/breaking-news/9693-never-abetter-time-for-automotive-marketers

McCracken, G. (1986). Culture and consumption: A theoretical account of the structure and movement of the cultural meaning of consumer goods. Journal of consumer research, 2, 71-84. 
Moradi, H. \& Zarei, A. (2012). Creating consumer-based brand equity for young Iranian consumers via country of origin sub-components effects. Asia Pacific Journal of Marketing and Logistics, 24(3), 394-413.

Nunnally, J. (1978). Psychometric methods. New York: McGraw.

Oliver, R. L. (1997). Satisfaction: A behavioral perspective on the customer. New York.

Pappu, R., Quester, P. G. \& Cooksey, R. W. (2005). Consumer-based brand equity: improving the measurement - empirical evidence. The Journal of Product and Brand Management, 14(3), 143154.

Pappu, R., Quester, P. G. \& Cooksey, R. W. (2006). Consumer-based brand equity and country-of-origin relationships: Some empirical evidence. European Journal of Marketing, 40(5-6), 697-717.

Pappu, R., Quester, P. G. \& Cooksey, R. W. (2007). Country image and consumer-based brand equity: relationships and implications for international marketing. Journal of International Business Studies, 38(5), 726-745.

Parkvithee, N. \& Miranda, M. J. (2012). The interaction effect of country-of-origin, brand equity and purchase involvement on consumer purchase intentions of clothing labels. Asia Pacific Journal of Marketing and Logistics, 24(1), 7-22.

Roth, K. P. Z., Diamantopoulos, A. \& Montesinos, M. A. (2008). Home country image, country brand equity and consumers' product preferences: an empirical study. Management International Review, 48(5), 577-602.

Roy, R. \& Chau, R. (2011). Consumer-based brand equity and status-seeking motivation for a global versus local brand. Asia Pacific Journal of Marketing and Logistics, 23(3), 270-284.

Scitovsky, T. (1976). The joyless economy: An inquiry into human satisfaction and consumer dissatisfaction.

Shahin, A., Kazemi, A. \& Mahyari, H. K. (2012). How Consumer's Perception of Country of Origin Affects Brand Equity: A Case Study in Iran. Middle-East Journal of Scientific Research, 12(6), 878-885.

Sharma, P. (2011). Country of origin effects in developed and emerging markets: Exploring the contrasting roles of materialism and value consciousness. Journal of International Business Studies, 42(2), 285-306.

Shukla, P. (2011). Impact of interpersonal influences, brand origin and brand image on luxury purchase intentions: Measuring interfunctional interactions and a cross-national comparison. Journal of world business, 46(2), 242-252.

Steenkamp, J. B. E., Batra, R. \& Alden, D. L. (2003). How perceived brand globalness creates brand value. Journal of International Business Studies, 34(1), 53-65.

Takali, H., Hamidi, M., Khabiri, M., Sajjadi, N. \& Alhani, F. (2012). The Analysis of Experts' Perceived Experience of the Effective Factors in Brand Equity of Iranian National Olympic Committee. World, 6(4), 441-451.

Tong, X. \& Hawley, J. M. (2009). Measuring customer-based brand equity: empirical evidence from the sportswear market in China. Journal of Product \& Brand Management, 18(4), 262-271.

Totton, N. \& White, P. (2011). The Ubiquitous Mythical Normal Distribution. UWE Bristol, July.

Verlegh, P. W. J., Steenkamp, J. E. M. \& Meulenberg, M. T. G. (2005). Country-of-origin effects in consumer processing of advertising claims. International Journal of Research in Marketing, 22(2), 127-139.

Yasin, N. M., Noor, N. M. \& Mohamad, O. (2007). Does image of country-of-origin matter to brand equity? Journal of Product \& Brand Management, 16(1), 38-48.

Yoo, B. \& Donthu, N. (2001). Developing and validating a multidimensional consumer-based brand equity scale. Journal of business research, 52(1), 1-14.

Zeithaml, V. A. (1988). Consumer perceptions of price, quality, and value: a means-end model and synthesis of evidence. The Journal of Marketing, 1, 2-22. 